\title{
Economics of Petroleum Exploitation and Exploration Impact on Selected Communities in Niger Delta Region of Nigeria
}

\author{
Prof P.O Idisi Afuye J.K \\ Department of Agricultural and Environmental Economics, University of Abuja, PMB 117, Gwagwalada, \\ Federal Capital Territory, Nigeria
}

\begin{abstract}
The study evaluated the economics of the petroleum exploitation and exploration impact on selected communities in Nigeria's Niger Delta region Nigeria. The following tools of analysis was used in achieving the specific objectives: Descriptive statistics, and Economic Analysis. The mean value of crude oil produce COP was $8.09 \mathrm{E}+08 \mathrm{bbl}(809165023.053)$, the average revenue generated from crude oil production over the period was $\$ 22,835,108$ USD. The average volume of gas flared was $462,230.5 \mathrm{~m}^{3}$ and the average revenue lost as the result of gas flaring was $\$ 254703.6$ USD the average volume of gas produced was $590.7150 \mathrm{~m}^{3}$ The average revenue generated from sales of crude oil was $\$ 22,835,108$ USD, the maximum revenue generated was $\$ 46,523,843$ USD. The average revenue generated from the sales of gas was $\$ 1,160,779$ USD, the maximum and minimum revenue was $\$ 46523843$ USD and $\$ 8029000$ respectively. The average revenue lost as a result of oil spillage over the period was $\$ 748.4895$ USD with maximum and minimum value of $\$ 3330.90$ USD and $\$ 24.60000$ USD. Table 4.2 also revealed that the average revenue lost as the result of gas flared over the specified period if it were properly harnessed was $\$ 254703$ USD, the maximum and minimum value of revenue lost was \$628332.0 USD and \$118337.0 USD.
\end{abstract}

Keywords: Economics, Petroleum, Exploitation, Revenue, Gas Flaring, Nigeria

DOI: $10.7176 / \mathrm{JESD} / 12-18-01$

Publication date:September $30^{\text {th }} 2021$

\section{INTRODUCTION}

\subsection{Background to the Study}

Oil and gas exploration and production are associated with many environmental and socioeconomic impacts (Baptiste \& Nordenstam, 2009 in George, 2010). Despite this, many nations throughout the world would still cherish to discover oil and gas within their territories. This is due to the fact that the availability of such natural resources is seen as a point of economic transformation and in fact can determine the development fortunes of such nations (George, 2010). With the world's population estimated to increase from the current 6 billion to about 9 billion in 2050 (medium population scenario; UN, 2003), it is logical that the world's energy level increases to meet the demands or at least be reliable in supply to meet the estimated requirements. Likewise, the level of food demand to feed this numerous population will also increase. Oil exploration started way back in the early 347 AD in China with the first well drilled (Song, 2016). Since then the world has been in the business of oil exploration and production. Legborsi (2007) summarizes the reasons why the world has a huge appetite for oil, and the role played by oil exploration in world politics. He asserts that, "the lives of people are affected and the destiny of nations is determined by the result of oil explorations". It is oil that ensures the workings of the industrialized countries, and provides the revenues that enables execution of ambitious national and economic development plans. If deprived of oil, the world will experience slow progress and life itself will be unbearable. Thus, oil plays a major role for economic development in many countries (Nanok, \& Onyango, 2017). As per data obtained from the International Energy Agency (2016) report total Africa's proven oil and gas reserves are estimated at 129.6 billion barrels and 496.7 tct (87.7 BoE) respectively. Africa makes up 7.5 percent to 7.8 percent of total proven oil and gas reserves in the world, and with more discoveries expected, its share contribution of proven reserves will rise.

Petroleum is undoubtedly the main backbone of the Nigerian economy, its discovery and exploration had introduced a considerable development in the country both financially and technologically (Audu, Abdulfatai, Saka Abdulkareema, \& Onyeji, 2016). Major deposits of Nigeria crude oil are found in the Niger-Delta area of the country. The Niger Delta is the major oil producing region of Nigeria, which is located by the Atlantic Coast where River Niger divides into numerous tributaries. The region is known to be the second largest delta in the world of about 450 kilometres of coast line that terminates at the Imo River entrance (Osuagwu, \& Olaifa, 2018). According to (Osuagwu, \& Olaifa, 2018), this region spans through 20,000 square kilometres and has been described as the largest wetland in Africa and among the three largest in the world, consisting about 2,370 square kilometres of rivers, creeks and estuaries and stagnant swamp covering about 8,600 square kilometres. The Niger Delta region of Nigeria is richly endowed with natural resources with oil and gas accounting for over $85 \%$ of the Nation's gross domestic product (GDP); over $95 \%$ of the National budget; and over $80 \%$ of the national wealth (Dokubo, 2004). Oil exploration and exploitation is the driving force of the Nigeria's economy with its attendant 
defects, one of which is the destruction of ecosystem (Michael, Lasbrey, Tobechi, Iyke, Uma, Kelvin, Sunday, \& Ikwor, 2019). Paradoxically, the region remains the poorest, due largely to the ecologically unfriendly exploitation of oil and state policies that expropriate the indigenous peoples of the Niger Delta of their rights to these natural resources. It is believed that since the advent of oil exploration some decades ago, the region has become the breadwinner of the nation, accounting for over $90 \%$ of the nation's export earnings since 1975 . The exploitation and exploration of oil have created some fortunes and contributed positively to the economy and technological advancement of the country as a whole (Audu, etal, 2016). For instance, it has been reported that oil exploration and exploitation in Nigeria provide $80 \%$ of the Nigerian revenue and $90 \%$ of its foreign exchange (Abdulkareem and Odigure, 2002; Abenege, 2004 in Audu, Abdulfatai, Saka, Ambali, \& Onyeji, 2016).

However, the accompanying socioeconomic and ecological fallout of oil exploration and exploitation is enormous. The activities of oil-producing companies operating in the Niger-Delta area of Nigeria resulted in various forms of environmental pollution, by way of relentless flaring and venting of gas to the environment, oil spillage, site clearing, deforestation and destruction of flora and fauna, and ecological disturbance in the $70 \mathrm{~km} 2$ Niger-Delta wetlands (Olukoga, 2002; Akpan, 2009; Agbalino \& Eyinal, 2009). Oil spillage is a global issue that has been occurring since the discovery of crude oil, which was part of the industrial revolution. In 1956, Shell British Petroleum (now Royal Dutch Shell) discovered crude oil at a village Oloibiri in Bayelsa state located within the Niger Delta of Nigeria (Onuoha, 2008; Anifowose, 2008) and commercial production began in 1958. Oil exploration and exploitation has been on-going for several decades in the Niger Delta. It has had disastrous impacts on the environment in the region and has adversely affected people inhabiting that region. The Niger Delta is among the ten most important wetland and marine ecosystems in the world. The oil industry located within this region has contributed immensely to the growth and development of the country which is a fact that cannot be disputed but unsustainable oil exploration activities has rendered the Niger Delta region one of the five most severely petroleum damaged ecosystems in the world. Studies have shown that the quantity of oil spilled over 50 years was at least 9-13 million barrels, which is equivalent to 50 Exxon Valdez spills (FME, et. al. 2006). The Niger Delta consist of diverse ecosystems of mangrove swamps, fresh water swamps, rain forest and is the largest wetland in Africa but due to oil pollution the area is now characterized by contaminated streams and rivers, forest destruction and biodiversity loss in general the area is an ecological wasteland. This affects the livelihood of the indigenous people who depend on the ecosystem services for survival (Kadafa, 2012).

Oil spillage is considered the most significant source of pollution from the petroleum industry because its effects are visible. Petroleum and it components released into the environment eventually degrade into both simple and complex compounds of their constituent elements by physical, physio-chemical, and biological agents, which may cause serious damages to the environment and impede human exploitation of natural resources (Abowei et al., 1997; Sanusi, 2004; Tolulope, 2004). Hence, the effects of oil spillage cannot be overemphasized and to be able to deal with the threat of oil spill quickly, Nigeria's Environmental Protection Agency (EPA) created the oil spill program (OSP) being run under the supervision of the EPA's emergency response program of the superfund. The OSP has been able to reduce the number of spills to less than $1 \%$ of the total volume handled each year (NOAA, 2008). However, the need for continued oil spill prevention and reduction is the desired interest of environmental interest groups, immediately affected communities, and the government alike. Gas flaring is another major problem associated with oil exploration and exploitation, considering the serious deterioration of the basic characteristics of the environment as a result of harmful pollutants being released into the air through gas flaring. The harmful effect of gas flaring on the host communities and the inability of the oil producing companies and the government to quantify the resultant effect of gas flaring have resulted in a violent relationship among the oil companies, government, and the host communities. It can be inferred therefore that both environmental and economic drives can be identified as the motives behind several attempts by the government at eliminating natural gas flares in Nigeria. For instance, are the promulgation of decrees and introduction of incentives for companies involved in downstream gas utilization to discontinue flaring of associated gas at well head, but none can be said to be fully successful so far (Abdulkareem and Odigure, 2010). It is argued in this study that ecologically unfriendly activities of the multinational corporations engaged in oil exploration have led to environmental degradation of the Niger Delta region which has in turn led to acute poverty in the region. It is the dynamics of this interconnectedness that this study intends to explore Economics of Petroleum Exploitation Impact on selected Communities in Nigeria's Niger Delta Region.

\subsection{Problem Statement}

The Niger Delta region is particularly famous for being the most natural resources endowed area in the country. The region is endowed with natural vegetation which are highly rich in biodiversity. It is the largest producer of cocoa, rubber, coconut, and a major producer of oil palm in the country. In view of such importance of the region, it is feared that uncontrolled oil and gas exploration and their associated activities could impact negatively on the surrounding terrestrial and aquatic ecosystem and biodiversity, institutions are not well 
established to effectively manage the associated environmental impacts. Meanwhile, it is apparent that such a project comes with a huge environmental impact which if not well managed could cost the nation more than the benefits derived. In extreme situations of improper environmental impact assessment and management, conflicts could be inevitable. Oil has indeed played a very significant role in the overall economic growth of the country. However, the adverse implications of petroleum exploration, exploitation and production are very severe as these have affected the micro economic indices of the host communities (Iloeje, 2016). Nigeria desires a growth pattern that aligned with sustainable ecological development (Michael, Lasbrey, Tobechi, Iyke, Uma, Kelvin, Sunday, \& Ikwor, 2019). The problem of environmental degradation due to expansion of oil production activities, the depletion of ozone layer, the emission of $\mathrm{CO}_{2}$ and other poisonous gas substances on people's health is the most challenging problem of the world today as reported by (Gul'nar, Sopilko, \& Illeritsky 2019), (Anyalechi, Chijindu, Josaphat, \& Okereke, 2019), Bassey 2001 and (Bekturganonva, Satybaldin, \& Yessekina 2019) in (Michael, Lasbrey, Tobechi, Iyke, Uma, Kelvin, Sunday, \& Ikwor, 2019). While most countries of the world faced natural hazards, Nigeria is faced with numerous technological and or human induced hazards, among which oil spills are leading with severe short and long term cumulative impacts on affected populace (Oshienemen, Dilanthi, and Richard, 2018). Nigeria experienced 9,343 incidences Oil spillage in 10 years (Kalejaye, 2015; and International Amnesty, 2015). Studies have also shown that the quantity of oil spilled in the Nigerian environment in five decades was at least 9-13million barrels, equivalent to (50) Exxon Valdez oil spills of 1989 (260,000 barrels; Wolfe, et al, 1994; Piatte et al, 1990). This positioned the region as one among five most ruthlessly petroleum damaged environment in the world (Kadafa, 2012; Anejionu, 2015). Consequently, these disasters have affected the environment, arable lands, water resources and livelihood structures of the immediate oil producing communities of Nigeria (Kadafa, 2012). The impact further degenerates to increase in poverty, crisis and unrest within the crude oil producing environment (Abegbulem, Ekpe \& Adejumo, 2013).

\subsection{Research Questions}

The following questions were raised to study the Economics of petroleum exploitation and exploration impact on the selected communities in Nigeria's Niger Delta Region.

The specific questions were:

(i) What are the quantities of oil spilled and the volume of gas flared that affects the environment in the Niger Delta?

(ii) What are the revenue lost from oil spillage and gas flared that would have been gained in the study area?

\subsection{Objectives of the Study}

The broad objective of this study is to analyze the Economics of Petroleum Exploitation Impact on selected Communities in Nigeria's Niger Delta Region.

This study was therefore carried out to provide answers to the following research questions. The specific objectives were to:

(i) To determine the quantities of oil spilled and the volume of gas flared that affects the environment in the Niger Delta

(ii) To estimate the revenue lost from oil spillage and gas flared that would have been gained in the study area.

\section{LITERATURE REVIEW}

According to (Nwilo and Badejo, 2010), between 1976 and 1996 alone, a total of 4647 incidents resulted in the spill of approximately 2,369,470 barrels of oil into the environment. Also, between 1997 and 2001, Nigeria recorded a total number of 2,097 oil spill incidents. The largest spill was the offshore well damage in January 1980, when at least 200,000 barrels of oil (8.4 million U.S. gallons), according to oil industry sources, spilled into the Atlantic Ocean from Texaco facility and destroyed 340 hectares of mangroves (Oil Spill Intelligence Report, 1998).

\subsection{The extent of oil spillage}

Oil spill incidents have occurred at different times along the Niger Delta area. From the records of the Department of Petroleum Resources (DPR 2002; DPR,2016), within the period 1976-2015, a total no of 16,476 spills occurred at different occasions and a total quantity of approximately 3 million barrels spilled into the environment. Unfortunately, more than $70 \%$ was not recovered, $69 \%$ of these spills occurred off-shore, a quarter was in swamps and 6\% spilled on land (Plessl et al, 2017). In (Osuagwu and Olaifa, 2018) the record from the Nigerian National Petroleum Corporation (NNPC) indicates that the amount of crude oil spilled into the Niger Delta is estimated at 2,300 cubic metres, on average over 300 spills occurred every year from 1975 to 1995. (Nwilo and Badejo, 2008) categorically describes the largest individual spills to include the blowout of a Texaco offshore station in 1980, which dumped an estimated 400,000 barrels $(64,000 \mathrm{~m} 3)$ of crude oil into the Gulf of 
Guinea and Royal Dutch Shell, Forcado Terminal tank failure with an estimated spillage of 580,000 barrels $(92,000 \mathrm{~m} 3)$. (Baird, 2010) has modestly estimated the quantity of petroleum products and crude oil spilled in the Niger Delta through oil exploration activities as falling between 9 million and 13 million barrels.

\subsection{Gas Flaring}

Natural gas is a gaseous phase of crude oil, and occurs in underground reservoirs and sometimes in association with crude oil (Tiratsoo, 1979). Natural gas flaring is an uncontrolled burning that is associated with crude oil production (Chokor, 2003). Gas flaring is the process of separating and burning of the gas produced from pumped oil resources from the ground (Elvidge et al, 2009). This is done by burning the separated gas in massive flares as waste into the air or environment. The Energetic Solution Conference (2004) estimates that the Niger Delta region has about 123 gas flaring sites. Agbola and Olurin (2003) stated that about 45.8 billion kilo watts of heat is discharged into the atmosphere from 1.8 billion cubic feet of gas daily in the Niger Delta region, leading to temperatures that render large areas inhabitable. Complete utilization of produced associated gas, reduction of flaring and production greenhouse gas is one of the policies that oil companies are expected to comply, with the stoppage of gas flaring completely by 2004 or 2008 . Still $84.60 \%$ of total gas produced is still flared with $14.86 \%$ only being used locally (Ukoli, 2005). From 1970-1986 a total of 125.5 cubic meters approximately of gas was produced in the Niger Delta region, $102.3(81.7 \%)$ million cubic meters was flared, 2.6 million cubic meter was used as fuel by the oil producing companies and about 14.6 million cubic meters was domestically consumed (Adati 2012). In 2004 Nigerian Liquefied Natural Gas pipeline transversing through Kala-Akama, Okrika mangrove forest leaked and set ablaze and burnt for three days. The local plant and animals within the areas were engulfed (Nenibarini, 2004). Apart from this fire incidence over several decades there have been many well documented cases of fire incidences that have resulted in a large number of human fatalities. Acid rain is another problem within the Niger Delta region caused by gas flaring which has led to loss in biodiversity, with forest and economic crops being destroyed. The dominance of grasses and shrubs in some parts of the region is indication of loss of natural forest, this may be due to acid rain but other factors maybe the cause such as agricultural activities and the exploration and exploitation of oil companies (Uyigue and Agho, 2007; Opukria and Ibaba, 2008). The concentration of acid in rain water appears to be higher in the Niger Delta region and decreases further away from the region (Uyigue and Agho, 2007). The heat generated from gas flaring kills vegetation around flaring area, destroys mangrove swamps and salt marshes, suppresses the growth and flowering of some plants, induces soil degradation and diminishes agricultural productivity (UNDP, 2006; Mba, 2000). A study by Adati (2012) and Adeyemo (2002) about the impact of gas flaring on agriculture showed a direct relationship between gas flaring and productivity decline in agriculture.

Flaring of Natural gas is a huge environmental problem in Niger Delta Region. Causing socioeconomic decline, health and environmental problems. Its environmental impacts are not only felt in communities with close proximity with the flared stacks, but also outside, through transboundary effects. It constitutes to global warnings by accumulating greenhouse gas emissions in the atmosphere. According to a November report by the Department of Petroleum Resources, $>70 \%$ of the oil fields in Nigeria still flare gas (Ugwaren, 2008). Specifically, Nigeria produces about 2.524 trillion SCF of gas annually and the estimated gas they utilize is put at $2.235 \mathrm{trn}$, with a hefty 289.6 bn SCF flared (Ajugwo, 2013). Oil companies operating in the country find it cheaper to flare gas than to conserve (Michael etal, 2019). Though it is illegal to do so, nevertheless corruption and dumbness has made the authorities not to care about the adverse environmental health hazards associated with it (Okonkwo et al., 2015; Uzoma and Mgbemena, 2015).

Gas Flaring is a widely used practice for the disposal of associated gas in oil production and processing facilities where there is insufficient infrastructure for utilization of the gas (primarily methane). The gas emerges from crude oil when it is brought to the surface and is separated from the oil prior to transport. Flaring activities have been linked to global warming. Global warming or climate change is a measurable increase in the average temperature of the Earth's atmosphere, oceans, and landmasses (Lee et al., 2007; Mathew, 2007; Soylu, 2007; Tzimas et al.,2007; Abdulkareem and Odigure, 2010). Scientists believe the Earth is currently facing a period of rapid warming brought on by rising levels of heat-trapping gases, known as greenhouse gases, in the atmosphere. Gas venting and gas flaring activities release huge amounts of greenhouse gases into the atmosphere. This activity has negative consequences on the environment such as flooding and reduced agricultural outputs. With this in mind, the need to control, regulate, and, if possible, end flaring cannot be overemphasized. Estimates suggest that of the 3.5 billion cubic feet $(100,000,000 \mathrm{~m} 3)$ of associated gas produced daily, 2.5 billion cubic feet $(70,000,000 \mathrm{~m} 3)$, or about $70 \%$, is wasted by flaring. This equals to about $25 \%$ of the UK's total annual natural gas consumption, and $40 \%$ of Africa's gas consumption in 2001 (Abdulkareem and Odigure, 2010). It has been reported that the gas flaring costs Nigeria about $\$ 2.5$ billion a year, with the waste reportedly enough to meet the electricity needs of the entire African continent. The reason for this economically and environmentally costly practice is that it is expensive to separate commercially viable associated gas from the oil. Akpan (2009) suggested that the only way out for harnessing the nation's natural gas is to encourage the establishment of gas- 
based petrochemical complexes that can consume the large volumes needed to eliminate gas flaring. In the same vein, Abdulkareem and Odigure (2010) worked on the economic benefit of natural gas utilization in Nigeria based on a case study of the food processing industry. Their work focused on the measurement of heat radiation from gas flaring as one of the menaces of gas flaring and the benefits of substituting conventional fuel and energy types, such as automotive gas oil (automotive gas oil-diesel), low pour fuel oil, and electricity with natural gas in monetary terms using mathematical principles in calculation with a case study of the food processing industry in Nigeria. Results obtained revealed that up to $69 \%$ on diesel, $29.85 \%$ on low pour fuel oil, and $69 \%$ on electricity could be saved by the company, translating to millions of dollars in five years if conventional fuel and energy are substituted with natural gas. Statistics about gas flaring in Nigeria and its impact on the environment are staggering. According to the National Oceanic and Atmospheric Administration (NOAA, 2008), Nigeria flared $532 \mathrm{Bcf}$ of natural gas in 2008, down from 593Bcf in 2007. Although there are no current estimates as to the cost of flaring the natural gas, in 2007, the Nigerian National Petroleum Cooperation (NNPC) claimed that flaring cost Nigeria US\$1.46 billion in lost revenue; however, critics consider that amount of revenue lost due to gas flaring is more than the amount quoted by the NNPC, since oil production levels determine the amount of associated gas produced, and thus bear on the amount of flaring. The rate and level of connection were summarized in a June 2001 speech by SPDC's former Chief Executive, Mr Basil Omiyi, where he stated that "On the average, about 1,000 standard cubic feet (scf) of gas is produced in Nigeria with every barrel of oil. Therefore, with oil production of some 2.2 million barrels per day, about 2.2 billion scf of associated gas is produced every day." With unreliable information on oil production levels, and conflicting information on associated gas production levels, it is difficult to be confident about flaring volumes in Nigeria.

\subsection{Economic Analyses}

Economic analyses were conducted on revenue generated from the sales of crude oil, revenue that would have been gain from the oil spilled and loss of revenue due to flaring of associated gas; these analyses will be based on the quantity of oil spilled, volume of gas flared and average selling price of crude oil per barrel and price per gallon of gas per year. (Audu et al, 2016) evaluated economics and environmental impacts of oil exploration and exploitation in Nigeria using economic analyses, the results revealed that Nigeria could have generated $\$ 790$ million in 1970 if all associated gas produced were to be harnessed, but due to flaring of associated gas \$759 million dollars in revenue were lost. The result also reveals that equivalent of $\$ 8.99$ billion dollars was lost in 1999 due to gas flaring. (Audu et al, 2016) also reported that the revenue generated from sales of crude oil. For instance, in 1970, the production rate of crude oil was $3.96 \times 10^{8}$ barrels, which is equivalent to a revenue generation of $\$ 1.43$ billion, while in 2010 the production rate was $7.37 \times 10^{8}$ barrels, equivalent to a revenue generation of $\$ 52.4$ billion.

Audu et al, (2016) evaluated Economics and environmental impacts of oil exploration and exploitation in Nigeria. Data were collected and analyzed on the volume of gas produced and flared in Nigeria between 1970 and 2010; also collected are the barrels of oil produced between 1970 and 2020 and the average price of barrel oil and gallon of gas between the said period. Results of analysis indicate that about $\$ 669$ billion was generated from the sales of crude oil between 1970 and 2010. Analysis of the collected data also showed that, between 1999 and 2010,742,983,000 m3 of gas was produced, equivalent to $\$ 192$ billion if harnessed and 587,375,000 $\mathrm{m} 3$ flared, representing $\$ 151.3$ billion loss of revenue.

\section{METHODOLOGY}

\subsection{The Study Area}

The Nigeria's coastline is approximately $853 \mathrm{~km}$ facing the Atlantic Ocean and lies between latitudes 40 10' to $6020^{\prime} \mathrm{N}$ and longitudes 2o $45^{\prime}$ to 8 o $35^{\prime} \mathrm{E}$ (Nwilo and Badejo, 2001).

The Niger Delta is located in the Atlantic coast of Southern Nigeria and is the world's second largest delta with a coastline of about $450 \mathrm{~km}$ which ends at Imo river entrance (Awosika, 1995). The Niger Delta includes the states of Abia, Akwa Ibom, Bayelsa, Cross River, Delta, Edo, Imo, Ondo and Rivers. The region is blessed with abundance of human and physical resources, including the majority of Nigeria's oil and gas deposits, good agricultural lands, extensive forests, excellent fisheries, as well as with a well-developed industrial base (Duru,2014:81 in Joseph et al, 2013). The region is about 20,000sq/km as it is the largest wetland in Africa and among the third largest in the world (Powell, et al., 1985; CLO, 2002; Anifowose, 2008; Chinweze and AbiolaOloke, 2009). 2,370sq/km of the Niger Delta area consists of rivers, creeks, estuaries and stagnant swamps cover approximately $8600 \mathrm{sq} / \mathrm{km}$, the Delta mangrove swamp spans about $1900 \mathrm{sq} / \mathrm{km}$ as the largest mangrove swamp in Africa (Awosika1995). The Niger Delta is classified as a tropical rainforest with ecosystems comprising of diverse species of flora and fauna both aquatic and terrestrial species (Kadafa,2012). The region can be classified into four ecological zones; coastal inland zone, freshwater zone, lowland rainforest zone, mangrove swamp zone and this region is considered one of the ten most important wetlands and marine ecosystems in the world. As of 1991, the National Census estimated about $25 \%$ of the entire Nigerian population 
lives within the Niger Delta region (Twumasi and Merem, 2006; Uyigue and Agho, 2007). The Niger Delta region has a steady growing population of approximately 30 million people as of 2005, accounting for more than $23 \%$ of Nigeria's total population Twumasi and Merem, 2006; Uyigue and Agho 2007).

\subsection{Methods of Data Collection}

This study involved the collection and analysis of data on crude oil production in Nigeria between 2000 and 2018. It also involves the analysis of data on gas production and flaring during the same period with the aim of predicting the amount of revenue generated through the exploitation and exploration of crude oil in Nigeria. Data was also collected on the volume of associated gas produced and the volume flared by multinational oil companies operating in the oil-producing region of Nigeria. Economic analyses were conducted on the revenue generated from the sales of crude oil and loss of revenue due to oil spillage and flaring of associated gas; these analyses was based on the average selling price of the crude oil per barrel and price per gallon of gas per year. This study employed time series data from 2000 to 2018 sourced from Central Bank of Nigeria Statistical Bulletin (2018), Department of Petroleum Resources (2018). The data for quantity of oil production and oil spill in barrels, was obtained from the Department of Petroleum Resources and Central Bank of Nigeria, Statistical Bulletin.

\subsection{Methods of Data Analysis}

The following tools of Analysis was applied to achieve the specific objectives of the study

Descriptive statistics

Economic Analysis

\subsubsection{Descriptive Statistics}

This was used to determine the summary of variables, which include means, percentages, minimum and maximum values, standard deviations and coefficients of variation, descriptive statistic was used to determine the extent of damages caused, by obtaining the average hectares of land degraded and water bodies contaminated as the result of oil spillage and gas flaring and also get the average quantity of oil spilled and gas flared, this was used to achieve the specific object (i)

\subsubsection{Economic Analysis}

Economic analyses were conducted on the revenue generated from the sales of crude oil and loss of revenue due to oil spillage and flaring of associated gas; these analyses was based on the quantity of oil produced and spilled, volume of gas produce and flared and also the average selling price of the crude oil per barrel and price per gallon of gas per year for the specified period of time under review.

The model is specified thus;

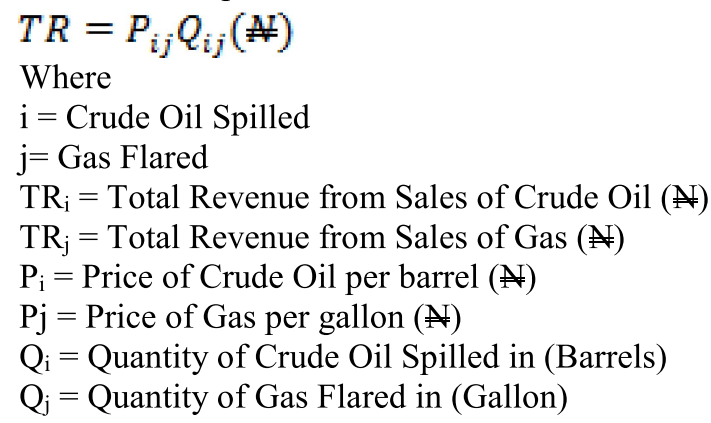

\section{RESULTS AND DISCUSION}

\subsection{Descriptive Statistics of the Variables}

Table 4.1 shows the summary statistics of the variable used for the study, the summary statistics provides means, medians, maximum, minimums, standard deviations, skewness, kurtosis and the Jarque-Bera tests including their p-values, for the variables crude oil produced (COP), revenue generated from the sales of crude oil (COREV), crude oil spilled (COSP), gas flared (GFLD), revenue lost as a result of gas flaring (GFLDREVLOS), gas produced (GP), revenue generated from gas production (GREV), revenue lost as a result of oil spillage (OILREVLOSS), and percentage of gas flared (PGFLD) over the period of 2000-2018. The purpose for the test was to check whether the observations were normally distributed. The mean value of crude oil produce COP was $8.09 \mathrm{E}+08 \mathrm{bbl}(809165023.053)$ with minimum and maximum values of $6.67 \mathrm{E}+08 \mathrm{bbl}$ and $9.19 \mathrm{E}+08 \mathrm{bbl}$ respectively. The average revenue generated from crude oil production over the period was $\$ 22,835,108$ billionUSD with maximum and minimum values of $\$ 46,523,843$ billion, $\$ 8029000$ billion while the average quantity of oil spill was 42,240.11bbl, this is in line with Aboje et al, 2016) that in 1970, the production rate of crude oil was $3.96 \times 108$ barrels, which is equivalent to a revenue generation of $\$ 1.43$ billion, while in 2010 the production rate was $7.37 \times 108$ barrels, equivalent to a revenue generation of $\$ 52.4$ billion. The average 
crop yield (yam) was $35,887,491$ tons tons while the quantity of fish output was 585405.6 tons. The average volume of gas flared was $462,230.5 \mathrm{~m}^{3}$ and the average revenue lost as the result of gas flaring was $\$ 254703.6$ USD the average volume of gas produced was $590.7150 \mathrm{~m}^{3}$. This result is also consistent with Aboje et al (2016) who reported that the rate of associated gas production increases the volume of flared gas, their analysis also reveals that Nigeria could have generated $\$ 790$ million in 1970 if all the associated gas produced were to be harnessed, but due to flaring of associated gas $\$ 759$ million dollars in revenue were lost, the average revenue generated from gas production over the specified period was $\$ 1,160,779$ billion with maximum and minimum value of $\$ 2436474, \$ 241000.0$ respectively. The average revenue lost as a result of oil spillage was $\$ 746.4895$ billionUSD and the maximum and minimum value was $3330.900,24.60000$ respectively. The mean percentage value of gas flared was $28.63842 \%$ while the maximum and the minimum percentage value of gas flared was $55.21000 \%$ and $9.940000 \%$ respectively. Research has also revealed that the flared gases that contribute immensely to air pollution are of great economic importance. For instance, the flared gases can be redirected into pipelines for domestic utilization in cooking and electricity power generation. This natural gas can serve as a feedstock to chemical and petrochemical industries to manufacture intermediate chemicals and finished product, such as ammonia, oxo-alcohols, methanol, fertilizer, etc. It can also be utilized by food industries for spray drying of coffee, milk products, etc. There is therefore the need to utilize the gas produced during the exploration and exploitation of oil in Niger delta region instead of flaring. The impact of gas flaring is of both local and global environmental concern as reported by (Ajayi, 1999), since the pollutants resulting from the flaring activity adversely affect the health of humans and animals and also cause plant and material damage, including environmental disorderliness which leads to low agricultural productivity (Abenege, 2004).

The standard deviation revealed the volatility level of the variables. It shows the rate at how each variable deviates from the mean value. GP is the less volatile with standard deviation of 233.8639 while COP is the most volatile at 809165023.053 .

Skewness measures the asymmetry of the probability distribution of a real-valued random variable about the mean. A normal distribution is symmetrical at point 0 . If the value is greater zero $(>0)$ it is said to be positively skewed, but if its less than zero $(<0)$ it is negatively skewed. Most of the variables are positively skewed as their values were greater than zero, only one variable has less than zero.

Kurtosis measures the sharpness of the peak of a normal distribution curve. It is a measure of tailedness of the probability distribution of a real-valued random variable. If the kurtosis value is approximately equal to 3 , it is known as mesokurtic distribution which implies that it is normally distributed. If it is approximately greater than 3 , it is leptokurtic distribution which has tails that asymptotically approaches zero slowly and has more outliers than normal distribution. More so if the value is less than 3 , it is playkurtic this signifies that the distribution produces fewer and less outliers than normal distribution.

The values of the following variables COP, COREV COSP, GP, GRV and GPFLD showed the evidence of platykurtic which is less than 3, while the values of COSP, GFLDREVLOS and OILREVLOSS shows leptokurtic which is greater than 3. GFLD revealed mesokurtic with value approximately equal to 3 .

The values of Jarque-Bera-test signifies that the sample was normally distributed the season was that the probability statistics of the variables are far away from zero. The farther the probability statistic of a variables to zero, the lower the value of its Jarque-Bera statistic and the more normally distributed the sample is and visa vis. This result is in agreement with the findings of Oluseun et al (2017) who reported that the probability of the Jarque-Bera statistic exceeds 5\% significance level for all the series tested, and found that the Jarque-Bera statistical values for all the variables were above the 0.05 significance level. This indicates that all the variables of interest satisfy the condition of normal distribution. Therefore, all the variables of interest meet the condition of symmetry and normal distribution. 
Table1: Description and Summary Statistics of the Quantity of oil spilled and Gas flared in the Study

\begin{tabular}{|c|c|c|c|c|c|c|}
\hline & \multicolumn{3}{|l|}{$\mathrm{COP}$} & \multicolumn{2}{|l|}{ COREV } & COSP \\
\hline Mean & \multicolumn{3}{|l|}{$8.09 \mathrm{E}+08$} & \multicolumn{2}{|l|}{22835108} & 42240.11 \\
\hline Median & \multicolumn{3}{|l|}{$8.03 \mathrm{E}+08$} & \multicolumn{2}{|l|}{16672130} & 17526.40 \\
\hline Maximum & \multicolumn{3}{|l|}{$9.19 \mathrm{E}+08$} & \multicolumn{2}{|l|}{46523843} & 241617.6 \\
\hline Minimum & \multicolumn{3}{|l|}{$6.67 \mathrm{E}+08$} & \multicolumn{2}{|l|}{8029000.} & 1659.000 \\
\hline Std. Dev. & \multicolumn{3}{|l|}{73803238} & \multicolumn{2}{|l|}{12553578} & 57475.07 \\
\hline Skewness & \multicolumn{3}{|l|}{-0.367985} & \multicolumn{2}{|l|}{0.514684} & 2.448437 \\
\hline Kurtosis & \multicolumn{3}{|l|}{2.213769} & \multicolumn{2}{|l|}{1.868188} & 8.780994 \\
\hline Jarque-Bera & \multicolumn{3}{|l|}{0.918183} & \multicolumn{2}{|l|}{1.852972} & 45.44109 \\
\hline Probability & \multicolumn{3}{|l|}{0.631857} & \multicolumn{2}{|l|}{0.395943} & 0.000000 \\
\hline Sum & \multicolumn{3}{|l|}{$1.54 \mathrm{E}+10$} & \multicolumn{2}{|l|}{$4.34 \mathrm{E}+08$} & 802562.0 \\
\hline Sum Sq. Dev. & \multicolumn{3}{|l|}{$9.80 \mathrm{E}+16$} & \multicolumn{2}{|l|}{$2.84 \mathrm{E}+15$} & $5.95 \mathrm{E}+10$ \\
\hline \multirow[t]{2}{*}{ Observations } & \multicolumn{3}{|l|}{19} & \multicolumn{2}{|l|}{19} & 19 \\
\hline & GFLD & GFLDREVLOS & GP & GREV & OILREVLOSS & PGFLD \\
\hline Mean & 462230.5 & 254703.6 & 590.7150 & 1160779. & 748.4895 & 28.63842 \\
\hline Median & 526801.0 & 205775.0 & 603.8500 & 1051994. & 418.3000 & 25.79000 \\
\hline Maximum & 759828.0 & 628332.0 & 920.9000 & 2436474. & 3330.900 & 55.21000 \\
\hline Minimum & 2777.800 & 118337.0 & 244.4000 & 241000.0 & 24.60000 & 9.940000 \\
\hline Std. Dev. & 252713.6 & 145057.0 & 233.8639 & 762449.1 & 925.3173 & 14.67265 \\
\hline Skewness & -1.019000 & 1.263879 & -0.095829 & 0.328945 & 1.966426 & 0.288256 \\
\hline Kurtosis & 2.694893 & 3.730996 & 1.537173 & 1.744339 & 5.697191 & 1.810808 \\
\hline Jarque-Bera & 3.538777 & 5.481433 & 1.813830 & 1.590857 & 18.00421 & 1.382682 \\
\hline Probability & 0.170437 & 0.064524 & 0.403768 & 0.451388 & 0.000123 & 0.500904 \\
\hline Sum & 9244611. & 4839369. & 11814.30 & 22054803 & 14221.30 & 544.1300 \\
\hline Sum Sq. Dev. & $1.21 \mathrm{E}+12$ & $3.79 \mathrm{E}+11$ & 1039154. & $1.05 \mathrm{E}+13$ & 15411819 & 3875.162 \\
\hline Observations & 19 & 19 & 19 & 19 & 19 & 19 \\
\hline
\end{tabular}

Source: Author (2020) Extracted from E-views 9.0

\subsection{Average Revenue generated from Crude Oil Production and Gas Produced as well as Revenue Lost from Oil Spills and Gas Flared from 2000-2018}

Table 2 show the results of the average revenue generated from crude oil production and gas produced and the revenue lost from oil spills and gas flared from the specified period from 2000-2018. The average revenue generated from sales of crude oil was $\$ 22,835,108$ billion USD, the maximum revenue generated was $\$ 46,523,843$ billion USD. This result is consistent with Aboje et al, (2016) who reported that $\$ 52.4$ billion was generated as revenue from the sales of crude oil per annun. The average revenue generated from the sales of gas was $\$ 1,160,779$ billion USD, the maximum and minimum revenue was \$46523843billion USD and \$8029000 respectively. The average revenue lost as a result of oil spillage over the period was $\$ 748.4895$ billion USD with maximum and minimum value of $\$ 3330.90$ billion USD and $\$ 24.60000$ billion USD. Table 4.2 also the study revealed that the average revenue lost as the result of gas flared over the specified period if it were properly harnessed was \$254703billion USD, the maximum and minimum value of revenue lost was \$628332.0billion USD and \$118337.0billion USD. This results is in line with (Audu et al, 2016) who reported that about \$669 billion was generated from the sales of crude oil between 1970 and 2010. Analysis of the collected data also showed that, between 1999 and 2010,742,983,000 m3 of gas was produced, equivalent to \$192 billion if harnessed and 587,375,000 m3 flared, representing \$151.3 billion loss of revenue. 
Table 2 Results of the Average Revenue generated from Crude Oil Production and Gas Produced as well as Revenue Loss from Oil Spill and Gas Flared from 2000-2018

\begin{tabular}{lcccc}
\hline & COREV & GREV & OILREVLOS & GFLDREVLOS \\
\hline Mean & 22835108 & 1160779. & 748.4895 & 254703.6 \\
Median & 16672130 & 1051994. & 418.3000 & 205775.0 \\
Maximum & 46523843 & 2436474. & 3330.900 & 628332.0 \\
Minimum & 8029000. & 241000.0 & 24.60000 & 118337.0 \\
Std. Dev. & 12553578 & 762449.1 & 925.3173 & 145057.0 \\
\hline Observations & 19 & 19 & 19 & 19
\end{tabular}

Source: Author (2020) Extracted from E-views 9.0

\section{CONCLUSION AND RECOMMENDATIONS}

The findings from this study revealed that the country has generated billions of dollars over the period studied but the inhabitants of the area could not benefit from the resources on their land. The Nigerian government has been able to build its economy through the benefits accruing from oil exploitation and exploration at the expense of the Niger Delta region who bear the social costs. These social costs in the form of air and water pollution, corrosion of materials and destruction of aquatic life, farms, flora and fauna; consequently, human life and the environment are affected from damages which are also inadequately compensated for. Since Nigerian government and foreign companies had been enjoying revenue generated as a result of Oil exploitation and exploration in the Niger delta region, therefore, Oil companies, and cooperate organizations operating in the region need to establish projects that truly deal with the needs of the people. Such projects should include health facilities, institutions/training centres, communication facilities, good roads, electricity, and pipe borne water. Based on our result, relatively low Natural Gas Flaring Penalty is generally seen as being responsible for the high level of natural gas flaring in Nigeria, the policy suggestion is to increase and set the natural Gas Flaring Penalty sufficiently high to achieve the desired policy goal. Relatively high natural gas flaring penalty could become the game changer in natural gas flaring reduction if implemented in combination with stringent environmental laws enforcement, increased investment in natural gas infrastructure and acquisition of flare reduction technology to incentivize natural gas marketization/utilization. Government agency such as National Oil Spillage Detective and Response Agency (NOSDRA) should be able to measure the land area mass and water body volumes degraded by oil spillage in order to know quantify the gravity of damage and degradation.

\section{REFERENCES}

Abdulkareem, A. S., \& Odigure, J. O. (2002). Radiative heat evaluation from gas flaring by computer simulation. J. Assoc. Adv. Model Simul. 72:1-10

Abdulkareem, A. S., \& Odigure, J. O. (2010). Economic benefit of natural gas utilization in Nigeria: A case study of the food processing industry. J. Energy Source Part B 5:106-114

Abenege, S. O. (2004). Modelling of pollutant dispersion from gas flaring: A case study of Niger-Delta Area. B. Eng. Thesis, Department of Chemical Engineering, Federal University of Technology, Minna, Nigeria (unpublished). 1-48

Abenege, S. O. (2004). Modelling of pollutant dispersion from gas flaring: A case study of Niger-Delta Area. B. Eng. Thesis, Department of Chemical Engineering, Federal University of Technology, Minna, Nigeria (unpublished). 1-48

Abowei, M. F. N., Susu, A. A., \& Onyeme, J. O. (1997). Oil Spill in Marine Environment. Lagos, Nigeria: CJC press (Nigeria) Ltd

Adati, A.K. (2012), Oil exploration and spillage in the Niger delta of Nigeria. Civil and Environmental Research Journal, 2, 38-51. Ajugwo, A.O. (2013), Negative effects of gas flaring: The Nigerian experience. Journal of Environment Pollution and Human Health, 1, 6-8.

Agbola, T. \& Olurin, T.A. (2003).Landuse and Landcover Change in the Niger Delta. Excerpts from a Research Report presented to the Centre for Democracy and Development.

Akpan, S. (2009). The production and utilisation of Natural gas resources in Nigeria: A review. Nigerian Annual International Conference and Exhibition in August of the Society of Petroleum Engineers in Abuja, Nigeria, 2009

Anejionu, O.C., P.-A.N. Ahiarammunnah, and C.J. Nri-ezedi, (2015). Hydrocarbon pollution in the Niger Delta: Geographies of impacts and appraisal of lapses in extant legal framework. Resources Policy, 2015. 45: p. 65-77. 7.

Anifowose, B. (2008). Assessing the Impact of Oil \& Gas Transport on Nigeria's Environment. U21 Postgraduate Research Conference Proceedings 1, University of Birmingham UK

Anifowose, B. (2008). Assessing the Impact of Oil \& Gas Transport on Nigeria's Environment. U21 
Postgraduate Research Conference Proceedings 1, University of Birmingham UK

Anyalechi, K.C., Chijindu, H.E., Josaphat, U.J.O., Okereke, E.J. (2019), Does oil price fluctuation affect stock market returns in Nigeria? International Journal of Energy Economics and Policy, 9(1), 194-199.

Audu, A., Abdulfatai J., Saka, Ambali, A., \& Onyeji, L. (2016). Economics and environmental impacts of oil exploration and exploitation in Nigeria, Energy Sources, Part B: Economics, Planning, and P0020ccolicy, 11:3, 251-257, DOI: 10.1080/15567249.2011.627411: http://dx.doi.org/10.1080/15567249.2011.627411

Audu, A., Abdulfatai J., Saka, Ambali, A., \& Onyeji, L. (2016). Economics and environmental impacts of oil exploration and exploitation in Nigeria, Energy Sources, Part B: Economics, Planning, and P0020ccolicy, 11:3, 251-257, DOI: 10.1080/15567249.2011.627411: http://dx.doi.org/10.1080/15567249.2011.627411

Awosika L.F. (1995). Impacts of Global Climate Change and Sea Level Rise on Coastal Resources and Energy Development in Nigeria. In: Umolu J.C., (ed). Global Climate Change: Impact on Energy Development. DAMTECH Nigeria Limited, Nigeria

Baird J. (2010) Oil Shame in Africa. Newsweek 27

Baptiste, A.K, and Nordenstam, B.J. (2009). Impact of oil and gas drilling in Trinidad: factors influencing environmental attitudes and behaviours within three rural wetland communities. Environmental Conservation. Pp 1-8. In Press.

Bassey, N. (2001), Oil and Gas in Africa: Ecological Debt Huge as the Sky. Paper Presented during the Globalization, Ecological Debt, Climate Change and Sustainability: A South South Conference, held in Benin, in November 21, Organized by Accison Ecological from Ecuador, Friends of the Earth, Benin and Friends of the Earth International

Bassey, N. (2001), Oil and Gas in Africa: Ecological Debt Huge as the Sky. Paper Presented during the Globalization, Ecological Debt, Climate Change and Sustainability: A South South Conference, held in Benin, in November 21, Organized by Accison Ecological from Ecuador, Friends of the Earth, Benin and Friends of the Earth International

Bekturganova, M., Satybaldin, A., Yessekina, B. (2019), Conceptual framework for the formation of low-carbon development: Kazakhstan's experience. International Journal of Energy Economics and Policy, 9(1), 48-56.

Chinweze, C. and Abiol-Oloke, G. (2009). Women Issues, Poverty and Social Challenges of Climate Changes in the Nigerian Niger Delta Context. 7th International Conference on the Human Dimension of Global Environmental Changes, UN Campus, Bonne, Germany

CLO, Civil Liberties Organization, (2002). Blood Trail: Repression and Resistance in the Niger Delta, Ikeja: CLO

Department of Petroleum Resources Statistical Bulletin, (2002)

Department of Petroleum Resources Statistical Bulletin, (2016)

Duru, C. U. (2014). Environmental Degradation: Key Challenge to Sustainable Economic Development in the Niger Delta. Doctoral Thesis, Walden University

Elvidge, C. D., Ziskin, D., Baugh, K. E., Tuttle, B. T., Ghosh, T., Pack, D. W. \& Zhizhin, M. (2009). A fifteen year record of global natural gas flaring derived from satellite data. Energies, 2(3): 595-622

George A. (2010) the potential impacts of oil and gas exploration and production on the coastal zone of Ghana An Ecosystem Services Approach MSc Thesis in Environmental Sciences Wage ningen University pp 1-9

Gul'nar, O.K., Sopilko, N.Y., Illeritsky, N.I. (2019), Republic of Turkey gas complex development: Problems and prospects. International Journal of Energy Economics and Policy, 9(1), 346-355.

Gul'nar, O.K., Sopilko, N.Y., Illeritsky, N.I. (2019), Republic of Turkey gas complex development: Problems and prospects. International Journal of Energy Economics and Policy, 9(1), 346-355.

Iloeje, A. F. (2016). Crude Oil Exploitation: The Environmental and Economic Implications to the Niger Delta People. IOSR Journal of Environmental Science, Toxicology and Food Technology .Volume 10, Issue 7 Ver. II (July 2016), PP 47-53 www.iosrjournals.org

Iloeje, A. F. (2016). Crude Oil Exploitation: The Environmental and Economic Implications to the Niger Delta People. IOSR Journal of Environmental Science, Toxicology and Food Technology .Volume 10, Issue 7 Ver. II (July 2016), PP 47-53 www.iosrjournals.org

International Amenesty. Nigeria: Hundreds of oil spills continue to blight Niger Delta. 201526 June2017];Availablefrom:https:/www.amnesty.org/en/latest/news/2015/03/hundreds-of-oil-spills-continueto-blight-niger-delta

International Energy Agency (2016). Mideum-term oil market report: Market analysis and forecast to 2021. World Energy Outlook 2015. IEA, p4

Kadafa, A.A., (2012) Environmental impacts of oil exploration and exploitation in the Niger Delta of Nigeria. Global Journal of Science Frontier Research Environment \& Earth Sciences, 2012. 12(3): p. 19-28.

Kadafa, A.A,(2012) Environmental impacts of oil exploration and exploitation in the Niger Delta of Nigeria. Global Journal of Science Frontier Research Environment \& Earth Sciences, 2012. 12(3): p. 19-28.

Kalejaye, K. (2015). Nigeria records 9,343 oil spill incidents in 10 years. 201526 June 2017]; 
Availablefrom:http://sweetcrudereports.com/2015/09/02/nigeria-records-9343-oil years/.

Lee, F. C., Lin, J. C., Lewis, C., and Chang, F. Y. (2007). Effects of Carbon Dioxide Taxes on Different Industries by Fuzzy Goal Programming: A case study of the petrochemical related industries, Taiwan Journal of Energy Policy 35:4051-4058.

Legborsi, S. P. (2007). The adverse impact of oil pollution on the enviroment and wellbeing of a local indegenous community: The experience of the Ogoni people of Nigeria (Paper presented at the forum of International Expert Group Meeting on Indigenous Peoples and Protection of the Environment ed.). Khabarovsk, Russian Federation: United Nations; Department of Economic and Social Affairs, p.16.

Mathews, J. (2007). Seven steps to curb global warming. J. Energy Policy 35:4247-4259

Mba, C.H. (2000). Environmental Protection and National Development: Towards Optimal Resolution of Conflicting Measures and Strategies. in: Aja Akpuru-Aja and Emeribe Augustine C., Policy and Contending Issues in Nigerian National Development Strategy. John Jacob's Publishers, Ltd, Enugu, Nigeria.

Michael O. E, Lasbrey, A . F. Tobechi, A., Iyke U U , Uma K. E.,. Kelvin, O .O, Sunday, A. O Ikwor, O .O (2019). Oil Exploration and Exploitation in Nigeria and the Challenge of Sustainable Development: An Assessment of the Niger Delta. International Journal of Energy Economics and Policy 9(4), 369-380. Available at http: www.econjournals.com

Nanok, J. K, and Onyango, C. O (2017). A socioeconomic and environmental analysis of the effects of oil exploration on the local community in Lokichar, Turkana County, Kenya, International Journal of Management, Economics and Social Sciences (IJMESS), ISSN 2304-1366, IJMESS International Publishers, Jersey City, NJ, Vol. 6, Iss. 3, pp. 144- 156 available at: http://hdl.handle.net/10419/171451

National Oceanic and Atmospheric Administration (2008). 13 May 2008. Available at: <http://www.noaa.gov/> National Oceanic and Atmospheric Administration (2008). 13 May 2008. Available at: http://www.noaa.gov/

Nenibarini, Z. (2004). Impacts of Extractive Industries on the Biodiversity of the Niger Delta. National Workshop on Coastal and Marine Biodiversity Management

Nwilo, P. C. and Badejo, O. T. (2001). Impacts of Oil Spills along the Nigerian Coast. Association for Environmental Health and Sciences Magazine

Nwilo, P.C. Badejo, O. T. (2008). Oil Dispersion and Trajectories on Nigerian open sea. The Conference Proceedings of the International Conference on the Nigeria State, Oil Industry and the Niger Delta, 164-192.

Oil Spill Intelligence Report (1998). Effect of Nigerian Spill Termed 'Minimal' as Last Known Patch Disperses. Vol. 21, no. 4

Okonkwo, C.N.P., Kumar, L., Taylor, S. (2015), The Niger Delta wetland ecosystem: What threatens it and why should we protect it? African Journal of Environmental Science and Technology, 9(5), 451-463

Olukoga, E. A. (2002). Natural gas as a vehicular fuel. Nigeria Gas Association International Gas Conference Exhibition, Abeokuta, Nigeria, pp. 22-26

Opukri, O.C.O. and Ibaba I.S. (2008). Oil Induced Environmental Degradation and Internal Population Displacement in the Nigeria's Niger Delta. Journal of Sustainable Development in Africa, 10(1)

Oshienemen N. A, Dilanthi, A., and Richard P. H (2018). Evaluation of the Impacts of Oil Spill Disaster on Communities and Its Influence on Restiveness in Niger Delta, Nigeria International Conference on Building Resilience; Using scientific knowledge to inform policy and practice in disaster risk reduction, ICBR2017, 27 - 29 November 2017, Bangkok, Thailand Vol 212 (2018) 1054-1061

Osuagwu, E.S, Olaifa E (2018) Effects of oil spills on fish production in the Niger Delta. PLoS ONE 13(10):e0205114.https://doi.org/10.1371/ journal.pone.0205114

Osuagwu, E.S, Olaifa E (2018) Effects of oil spills on fish production in the Niger Delta. PLoS ONE 13(10):e0205114.https://doi.org/10.1371/ journal.pone.0205114

Piatt, J.F., (1990). Immediate impact of the 'Exxon Valdez'oil spill on marine birds. The Auk, 1990: p. 387-397.

Plessl, C., Otachi, E.O., Körner, W., Avenant-Oldewage, A., Jirsa, F. (2017), Fish as bioindicators for trace element pollution from two contrasting lakes in the Eastern rift valley, Kenya: Spatial and temporal aspects. Environmental Science and Pollution Research, 24, 19767-19776.

Powell, C.B., White, S.A., Ibiebele, D.O., Bara, M., Dut Kwicz, B., Isoun, M. and Oteogbu, F.U. (1985). Oshika Oil Spill Environmental Impact; effect on Aquatic biology. Paper presented at NNPC/FMHE International Seminar on petroleum industry and the Nigerian Environment 11 - 13 Nov. 1985, Kaduna, Nigeria 168 178

Sanusi, S. (2004). Mathematical Modelling and Computer Simulation of Oil Spillage in Soil. B.Eng Degree Project Unpublished. Federal University of Technology, Minna, Niger State, Nigeria, pp 1-53

Song, S. (2016). The perfect play of salt, bamboo and gas. AAPG 2016 Annual Convention \& Exhibition. Calgary: College of Geoscience

Twumasi, Y. and Merem E. (2006). GIS and Remote Sensing Applications in the Assessment of Change within a 
Coastal Environment in the Niger Delta Region of Nigeria. International Journal of Environmental Research \& Public Health, 3(1):98- 106

Tzimas, E., Mercier, A., Cormos, C., and Peteves, S. D. (2007). Trade-off emissions of acid gas pollutants and of $\mathrm{CO}_{2}$ in fossil fuel power plants with carbon capture. J. Energy Policy 35:3991-3998.

Ugwaren, I. (2008), Groups Petition National Assembly on 2008 Gas Faring Deadline. Lagos: This Day

Ukoli, M.K. (2005). Environmental Factors in the Management of the Oil and Gas Industry in Nigeria. www.cenbank.org

UN (2003). World Population Prospects; The 2002 Revision. Population Division, Department of Economic and Social Affairs, United Nations, New York

Uyigue, E. and Agho, M. (2007). Coping with Climate Change and Environmental Degradation in the Niger Delta of Southern Nigeria. Community Research and Development Centre Nigeria (CREDC) 